\author{
References \\ Taye T 2005. MSc thesis, Haramaya University. 105+xiv. \\ Mwacharo JM and Drucker AG 2005. Tropical Animal Health and Production 37, 635-652.
}

doi:10.1017/S2040470010000221

\title{
Phenotypic characterization of the local goat in Mauritius
}

\author{
Saraye Geerjanand ${ }^{\dagger}$
}

Agricultural Research and Extension Unit, Newry complex, 230 Quatre Bornes, Mauritius

Introduction

Goat rearing has always been an important activity for meat production in the rural and sub-urban areas of Mauritius, representing an additional source of revenue and a cash reserve for many farmers. In 2005 there were about 16500 heads of goats and 2500 goat farmers in the country (Anon, 2005). Most of the goats are kept in small units of 5-10 heads under backyard production systems whereby the animals are confined to their sheds and fodder is provided on a cut-and-carry basis. However, there are also many farms where the flock size varies from 10 to 25 and a few with flocks exceeding 25 heads.

Goats were first introduced into Mauritius in 1606, when a Dutch admiral is reported to have left 24 goats on the island (Lestrac (de) J.C, 2007). The local goats are descendants of this first population of goats and have for many centuries been subjected to the particular local environmental conditions. As a result, they have developed certain valuable genetic traits such as ability to perform under low input condition and climatic stress and resistance to infectious diseases and parasitism. The local breed was regarded as less productive and therefore subjected to replacement and cross-breeding with imported breeds like British Alpine, Anglo Nubian, Jumna Pari and Boer introduced at different periods since 1950. This has resulted in a drastic reduction in the number of local goats (breed substitution) and the loss of their characteristics (genetic erosion). The genetic purity of the local breed is now under severe threat due to indiscriminate adoption of exotic breeds.

This study therefore aimed to phenotypically characterise the local goat in view of establishing a database for the breed for use in future upgrading and breeding programmes.

\section{Materials and methods}

Traditional goat farms (117) were randomly selected and surveyed islandwide in 2005. Records on morphological characteristics were taken on 347 (151 males and 196 females) adult animals randomly selected on the farms. Traits scored were presence or absence of horns, shape of horns, orientation of horns, presence or absence of wattles, types of ears, color of coat, texture of coat, face profile, rump profile, back profile, orientation of ears, coat type, score of hair length and presence or absence of beard for each animal. The sex of each animal was also recorded.

\section{Results}

The study showed that mature males averaged $57.9 \pm 5.5 \mathrm{~cm}$ at the shoulder, had an average chest-girth of $68.9 \pm 7.2 \mathrm{~cm}$, an average body length of $58.2 \pm 8.7 \mathrm{~cm}$ and an average body weight of $25.2 \pm 5.1 \mathrm{~kg}$. In mature females shoulder height averaged $54.6 \pm 5.0 \mathrm{~cm}$, chest-girth $66.7 \pm 6.5 \mathrm{~cm}$, body length $56.0 \pm 6.3 \mathrm{~cm}$ and body weight $23.9 \pm 5.5 \mathrm{~kg}$. Most of the animals, $61.7 \%$ were of uniform color; black, being the most common of goats, $48.7 \%$, followed by $6.9 \%$ white and $6.1 \%$ brown. The animals $(68.3 \%)$ showed mixed or other combinations of colors in varying proportions. Hairs were generally short and straight. Less than $2 \%$ of animals had short curly or long straight hair. The facial profile was predominantly straight (flat) with only $4.0 \%$ of the animals having convex or concave profiles. Ears were carried laterally in $85.0 \%$ and horizontally forward in $3.2 \%$ of the animals. The animals $(4.3 \%$ and $6.1 \%)$ had erect and pendulous ears respectively. Ears averaged $13.4 \pm 2.0 \mathrm{~cm}$ in length. Males (59.9\%) carried beards as compared to only $12.8 \%$ of females. Horns were present in $95.4 \%$ of animals but $7.0 \%$ had only rudimentary horns or scurs. The horns generally grew in a backward curve (45.2\%) or straight backwards (18.2\%). Animals $(48.1 \%)$ had long horns $(>8 \mathrm{~cm}), 44.9 \%$ had horns of medium length $(2-8 \mathrm{~cm})$ and $7.1 \%$ had short horns $(<2 \mathrm{~cm})$.

\section{Conclusion}

The local goat can be characterized as a small to medium size (Galal, 2007) breed with variable coat color and pattern, short straight hair, straight facial profile, medium size laterally carried ears and predominantly horned. Since the breed has been acclimatized to the local environment there is an urgent need to conserve and use it in a breeding programme.

\footnotetext{
†E-mail: nimishe@yahoo.com
} 


\title{
References
}

Anon, Digest of agricultural Statistics 2005.

Lestrac (de) J-C 2007. Mauriciens, enfants de mille races, I, Au temps de l'lle de France. Aditions Le Printemps, lle Maurice, $270 \mathrm{p}$.

Galal S 2007. Biodiversity in goats In Small ruminants 60 (1-2), 75:81.

\section{Management of local genetic resources by in situ and ex situ methods for research and breeding purpose: the case study of the local animal breeds of Guadeloupe and Martinique}

\author{
Michel J. Naves ${ }^{1 \dagger}{ }^{\text {, Rémy }}$ Arquet $^{2}$, Alain Farant ${ }^{2}$, Félix X. Quenais ${ }^{1}$, Jean Luc Gourdine ${ }^{1}$ and \\ Nathalie Mandonnet ${ }^{1}$
}

${ }^{1}$ INRA UR 143 Unité de Recherches Zootechniques, Antilles-Guyane, Duclos, 97170 Petit Bourg, Guadeloupe; ${ }^{2}$ INRA UE 1294 Plateforme tropicale d'expérimentation sur l'animal, Domaine de Gardel, 97160 Le Moule, Guadeloupe

Few studies are implemented towards the management of local genetic resources specifically in the tropics, although there is an urgent need for preservation and breeding improvement of these hardy genotypes. The local breeds of ruminants and pigs of Guadeloupe and Martinique derive from Spanish and African animals, imported in the Caribbean during history. These breeds are of great interest for research and breeding purposes, since they obtain a high productivity and present a natural resistance to diseases transmitted by ticks, for Creole cattle of Guadeloupe, a useful genetic variability for resistance to gastrointestinal strongyles, for Martinik hair sheep and Creole goats, and a great tolerance to heat stress for the Creole pig. They represent valuable resources in the breeding systems practiced in Guadeloupe and Martinique (Gunia, 2010). However some breeders have created breeding associations, recognized by the French Ministry of Agriculture in order to maintain and improve these breeds on the field, in private herds. INRA is also conducting research on the characterization and preservation of these breeds. Their purpose is mainly the implementation of a sound genetic improvement program for both production and adaptation traits, and a better understanding of their adaptation to tropical conditions.

Experimental flocks of about 90 Creole cows, 250 Creole goats, 150 Martinik hair sheep, and 25 Creole sows, are managed as nucleus herds. The complete genealogy is known on about three generations for cattle, 12 for goats, 18 for sheep, and 16 for pigs. The goat nucleus is closed, while the cattle, sheep and pig nuclei are open for sires from private herds. The mean inbreeding coefficient is less than $1 \%$ in cattle, about $2.3 \%$, for goats, $1.6 \%$ in sheep, and $13 \%$ for pigs. The breeding management is rationally performed to keep consanguinity as low as possible. Inventory and management of the base population at the island level is managed by the professional organization, in accordance with the European and French regulations for genetic resource conservation and management programs. Cryopreservation is implemented and a biological resource centre has been equipped in order to conserve biological material, in relation with the national French policy for genetic resource management. Embryos and semen are stored, according to the recommendations applied in the National Cryobank (Danchin-Burge et al., 2006). In goats, a total of 256 frozen embryos from 16 donors are stored by the French National Cryobank, and 1300 doses of semen from 22 bucks are stored in local facilities. In cattle, the semen of 21 bulls has been collected, representing a total of 7200 doses of semen. The same is planned in pigs and sheep. A sample of sires representative of the base populations will also be collected and their semen stored, in the different species.

Genetic research is conducted, and a collection of DNA and other biological samples (blood, cells and tissues) has been initiated for molecular genetics studies. More than 8500 samples are currently stored, with an increment of about 900 samples per year. A set of the base population representative of the diversity in each species is under characterization for a panel of microsatellites or SNP, in cattle, pigs and goats. Other genetic studies are also underway, as the research of QTL for production and adaptation traits in goats and cattle (Chevrotière et al., 2010 or Assenza et al., 2010). Through these activities, combining in situ and ex situ methods for research and breeding purposes, INRA is highly committed in the characterization, preservation and improvement of local genetic resources valuable for the humid tropics, and especially for the Caribbean, in accordance with the regional priorities defined by the FAO in 2007.

\section{References}

Assenza F, Menendez Buxadera A, Gourdine JL, Farant A, Bocage B, Godard X and Naves M 2010. Genotype by environment interaction on growth and carcass traits inf beef cattle in the tropics. Conference "Sustainable Animal Production in the Tropics", Gosier, Guadeloupe, 15-18 November 2010.

Chevrotière $C$. de la 2010. Contributions of the Creole goat model to the understanding of the genetic resistance to gastrointestinal nematode infections. Conference "Sustainable Animal Production in the Tropics", Gosier, Guadeloupe, 15-18 November 2010.

\footnotetext{
† E-mail: michel.naves@antilles.inra.fr
} 